\title{
New record for the deep-sea genus Tripoplax (Mollusca: Polyplacophora) in the eastern Pacific
}

\author{
Nancy Yolimar Suárez-Mozo ${ }^{1 *}$ and Michel E. Hendrickx²
}

\begin{abstract}
Background: Most species of Polyplacophora are found in shallow, coastal water, and their distribution and ecology is generally well known. On the contrary, information related with distribution, biology and ecology of deep-sea chitons is scarce.

Methods: Specimens of the deep-sea mollusks fauna were obtained during sampling operations of western Mexico (TALUD project) aimed at the study of invertebrate fauna occurring under the Oxygen Minimum Zone (OMZ). The material reported herein is part of the Polyplacophora fauna collected with a benthic sledge off the west coast of the Baja California Peninsula, in the eastern Pacific, Mexico.

Results: The deep-sea chiton Tripoplax cf. balaenophila Schwabe \& Sellanes 2004 was collected in 530-625 m depth, in the following environmental conditions: dissolved oxygen, $<0.25 \mathrm{ml} / /$; temperature, $6.44{ }^{\circ} \mathrm{C}$; salinity, 34.47 . It represents a range extension of $63^{\circ}$ of latitude $(c a 8280 \mathrm{~km})$ to the north for this species previously known only from the type locality, off Concepción, Chile.

Conclusions: Tripoplax cf. balaenophila is associated with the lower boundary of the Minimum Oxygen Zone occurring off western Mexico, an habitat characterized by severe hypoxic conditions and colonized by well-adapted species that are generally abundant. Assignment of species to Tripoplax or Lepidozona is still a conflictive issue. The existing discrepancy in slit number and the assignment of "balaenophila" to Tripoplax cannot be solved without a more thorough review of both genera. The disjunct distribution of the genera Tripoplax in the eastern Pacific is also an interesting biogeographical issue.
\end{abstract}

Keywords: Polyplacophora, Tripoplax cf. balaenophila, Eastern Pacific, Mexico

\section{Background}

Polyplacophora include about 900 extant species worldwide, most living in shallow water on rocky substrates (Schwabe \& Sellanes 2010; Ávila \& Sigwart 2013). In addition, about 430 fossil species have been described (Puchalski et al. 2008). About 24 species have been recorded from the abyssal and hadal zones (Schwabe 2008).

Information dealing with chitons from the Mexican Pacific is available in several contributions (e.g., ReyesGómez \& Salcedo-Vargas 2002; Reyes-Gómez 2004;

\footnotetext{
* Correspondence: nancy-yolimar@hotmail.com

${ }^{1}$ Posgrado en Ciencias del Mar y Limnología, Universidad Nacional Autónoma de México, Unidad Académica Mazatlán, Mazatlán, Sinaloa, México

Full list of author information is available at the end of the article
}

Flores-Campaña et al. 2007; Galeana-Rebolledo et al. 2012; Hendrickx et al. 2014; Ramírez-Álvarez et al. 2014). On the contrary, studies related to deep-water ( $>200 \mathrm{~m}$ depth) species are few and very little is known on their distribution and biology (Stebbins \& Eernisse 2009; Galeana-Rebolledo et al. 2012). Most information on deep-water chitons is found in taxonomic and monographic studies that often provide interesting information related to geographic and bathymetric ranges (Dall 1919; Ferreira 1979; Kaas \& Van Belle 1985, 1987, 1990; Clark 2008), but very few data are provided regarding ecological aspects.

At deep-sea bottom soft substrates predominate and this habitat is not adequate for chitons. Hence, their occurrence is generally linked to the presence of hard 
substrates like rocks and rocky structure (Stebbins \& Eernisse 2009), dead wood (Sirenko 2004), and unusually osseous remains of dead whales (Schwabe \& Sellanes 2004). Chitons have also been recorded from hot-vents and cold-seeps (Saito et al. 2008), canyons (Clark 2008), and seamounts (Stocks 2004).

During an exploratory cruise off western Mexico, specimens of a species of the deep-sea genus Tripoplax were collected. This material is reported here and represents a significant range extension for a species described for Chile.

\section{Results and discussion SYSTEMATICS}

Class Polyplacophora Gray, 1821

Order Chitonida Thiele, 1909

Suborder Chitonina Thiele, 1909

Family Ischnochitonidae Dall, 1889

Genus Tripoplax Berry, 1919

Tripoplax cf. balaenophila (Schwabe \& Sellanes, 2004)

Fig. 1

\section{Material examined}

TALUD XV, St. 23, 2708'11"N, 114'32'54"W, August 1, 2012, 5 specimens (TL 6.82-13.76 mm), benthic sledge, 530-625 m depth (EMU-10816 and 10817).

\section{Morphological remarks}

Small-sized animal (TL, 13.76, 11.21, 10.22, 6.98 and $6.82 \mathrm{~mm}$ ) (Fig. 1i, j). Color yellowish-beige, girdle of the same ground color, with slightly darker bands. Tegmentum. General valve sculpture consisting of very fine granules arranged in quincunx (Fig. 1a, c, e), readily visible on the head valve, lateral areas and postmucronal area. Articulamentum consisting of a thin translucent white layer. Insertion plates short, with broad, sharp teeth (Fig. 1b, f). Slit formula: 10/1-2/17 (vs. 10/1-2/12 in the holotype), slit rays present. Ctenidia (or gills) in a holobranchial arrangement, left and right series of ctenidia counting 17-18 (Fig. 1j). Perinotum. Girdle rather small, covered with larger rectangular scales $(>100 \mu \mathrm{m})$, the later sculptured with about 10 radial ribs (Fig. 1g, h). Radula (Fig. 1k, l). Central tooth slender, narrower in its middle part, provided with a small, upper fold inclined downwards. First lateral tooth shorter than central; turbercule-like structure in the corner of the blade directed outward. Second lateral tooth with inner denticle sharp, nearly twice as long as outer one; outer denticles obtuse. Major uncinal tooth slender, a lateral fold at mid-third, tip flattened, round, paddle-like.

General features of the examined material fit well with the original description (Schwabe \& Sellanes 2004). However, although quite similar, girdle scales are proportionally larger and more rectangular in the Mexican specimens. The central tooth of the radula shows a distinctly different shape compared to these tooth in the original description of $T$. balaenophila, i.e., rectangular with a forward and downward bent single blade. The first lateral tooth is shorter in relation to the central one in our specimen and the tubercule-like structure in the corner of the blade is directed outward vs. inward directed in $T$. balaenophila.

Photographs of one specimen (TL, $11.21 \mathrm{~mm}$; Fig. 1i, j) of T. cf. balaenophila were sent to Boris Sirenko who suggested that it could belong to that species (B. Sirenko, pers. comm., January 2015). SEM photographs of the radula and the girdles scales were sent to Enrico Schwabe who emphasized the similarity between $T$. balaenophila and our material, but suggested that the variations observed in the radula and in the girdles scales might indicated that the material reported herein represents a species very close yet distinct to T. balaenophila (E. Schwabe, pers. comm., September 2015). The differences observed might be significant, but a more profound revision is needed, including comparing the material with other species in the context of a thorough revision of Tripoplax (and Lepidozona), both morphologically and using molecular markers.

\section{Environmental conditions}

The species was collected at 530-625 m depth in the following environmental conditions: dissolved oxygen, $<0.25 \mathrm{ml} / \mathrm{l}$; temperature, $6.44{ }^{\circ} \mathrm{C}$; salinity, 34.47 .

\section{Type locality}

Off Concepción, Chile, $36^{\circ} 29.9^{\prime} \mathrm{S} ; 7^{\circ} 40.8^{\prime} \mathrm{W}$ (Fig. 2), in $240 \mathrm{~m}$ depth, just beneath the shelf break, mostly attached to bones of dead whales and rocks.

\section{Distribution and habitat}

The presence of $T$. balaenophila off western Mexico would considerably extends its geographic range by over $63^{\circ}$ of latitude (ca $8280 \mathrm{~km}$ ) to Baja California $\left(27^{\circ} 08^{\prime}\right.$ $11^{\prime \prime} \mathrm{N} ; 114^{\circ} 32^{\prime} 54^{\prime \prime} \mathrm{W}$ ) (Fig. 2), and its bathymetric range to $530-625 \mathrm{~m}$. There was no evidence of osseous remains in the sample and we believe that the specimens were probably attached to the rocks found in the net, and that were accidently collected. There was no indication that the sample was obtained from a chemosynthetic environment, as hypothesized earlier (Schwabe \& Sellanes 2004). It is clear, however, that our material was collected just below the Oxygen Minimum Zone (OMZ) in severe hypoxic conditions $\left(<0.25 \mathrm{ml} / \mathrm{l} \mathrm{O}_{2}\right)$. The OMZ has long been recognized as an ecologically important feature of the eastern Pacific, including western Mexico (Diaz \& Rosenberg 1995; Hendrickx \& Serrano 2010; Serrano 2012). According to published information (Schwabe \& Sellanes 2004; Sellanes et al. 2010), the 


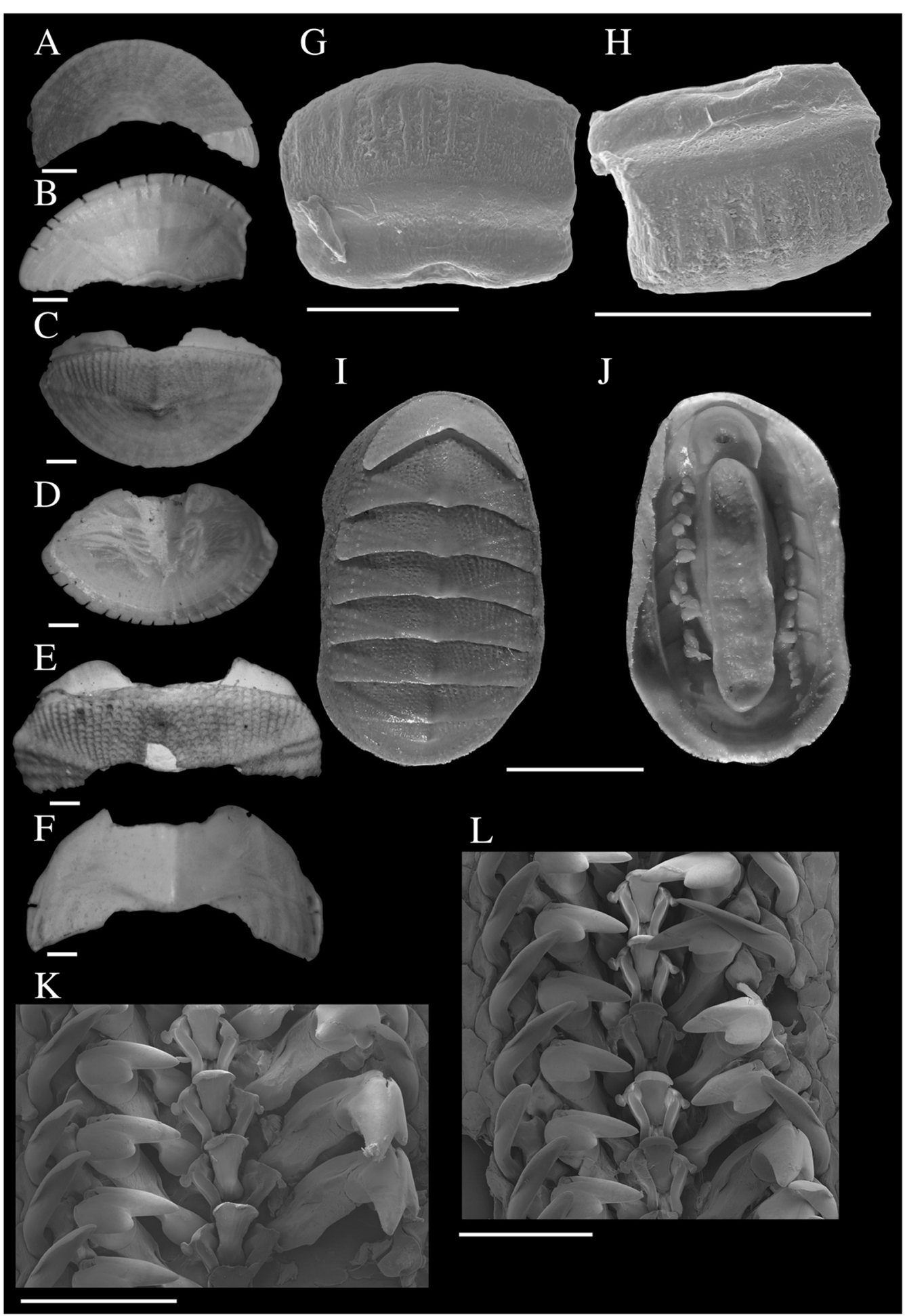

Fig. 1 Tripoplax cf. balaenophila (Schwabe \& Sellanes, 2004) (EMU-10817). a-f, TL 13.76 mm; H-I, TL 11.21 mm. a Dorsal view of first valve, scale bar: $1 \mathrm{~mm}$. b Ventral view of the first valve, scale bar: $1 \mathrm{~mm}$. c Dorsal view of the tail valve, scale bar: $1 \mathrm{~mm}$. $\mathbf{d}$ Ventral view of the tail valve, scale bar: $1 \mathrm{~mm}$. e Dorsal view of valve $\mathbf{v}$, scale bar: $1 \mathrm{~mm}$. $\mathbf{f}$ ventral view of valve $\mathbf{v}$, scale bar: $1 \mathrm{~mm}$. $\mathbf{g}$ Dorsal girdle scales, scale bar: $100 \mu \mathrm{m}$. $\mathbf{h}$ Lateral view girdle scales, scale bar: $200 \mu \mathrm{m}$. i Dorsal view, head region on top, scale bar: $5 \mathrm{~mm}$. $\mathbf{j}$ Ventral view, head region on top, scale bar: $5 \mathrm{~mm}$. k Detail of radula, showing teeth, scale bar: $200 \mu \mathrm{m}$. I Anterior portion of radula, scale bar: $200 \mu \mathrm{m}$ 


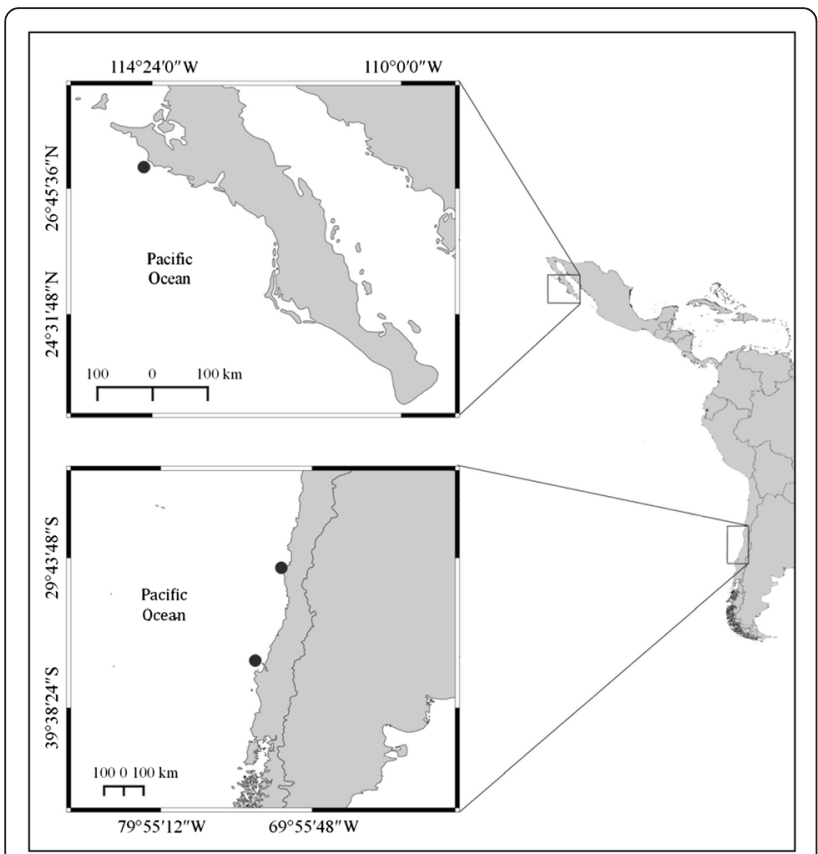

Fig. 2 Sampling localities of the deep-water chiton Tripoplax cf. balaenophila off Baja California, Mexico (upper map), off Concepción (data extracted from Schwabe \& Sellanes, 2004), and off Coquimbo, Chile (E. Schwabe, pers. comm., April 2015) (lower map)

specimens from Chile were collected in bottom water with severe oxygen deficiency $(<0.5 \mathrm{ml} / \mathrm{l})$. The amplitude of the OMZ corresponding to upper and lower oxygen concentrations of $0.5 \mathrm{ml} / \mathrm{l}$ is reduced and shallower off Concepción, in southern Chile (from 50 to $150 \mathrm{~m}$ depth) (Helly \& Levin 2004) when compared to the conditions found at the Mexican sampling locality (TALUD XV, St. 23, from 90 to $>630 \mathrm{~m}$ depth) (D. Serrano, pers. comm., April 2015). In this area $\left(\right.$ ca $\left.27^{\circ} \mathrm{N}\right)$, the OMZ fringe corresponding to concentrations of $0.5 \mathrm{ml} / \mathrm{l}$ extends from 200 to 750 m (Helly \& Levin 2004), a similar range as what is shown by the TALUD XV cruise data. This probably explained why the Mexican material was collected in deeper water than off Chile. On the other hand, it is reasonable to assume that $T$. balaenophila occurs in the wide latitudinal interval between Chile and western Mexico and that lack of additional records of this species is due to lack of sampling. As a matter of fact, an additional, unpublished record of $T$ balaenophila is available for a second Chilean locality: off Coquimbo, $30.3815^{\circ} \mathrm{S}$, $71.9626^{\circ} \mathrm{W}$, in $140 \mathrm{~m}$ depth (Bavarian State Collection of Zoology, Munich, Germany, Mol 20130032, 5 specimens; Enrico Schwabe, pers. comm., April 2015: coll. J. Sellanes). According to data available for this area (Helly \& Levin 2004), this material was obtained close to the lower boundary of the OMZ.

\section{Additional comments}

The subgenus Tripoplax was originally proposed in 1919 (Berry 1919) within the genus Ischnochiton Gray, 1847. Tripoplax and Lepidozona have been considered as subgenera of Lepidozona Pilsbry, 1892 (Kaas \& Van Belle 1987; Clark 1991, 2000; Eernisse 1998). Tripoplax has also been considered a natural assemblage based of its morphology and biogeography and elevated to genus (Clark 2008). An expanded definition of Tripoplax (Clark 2008) clearly stated that "insertion plates of intermediate valves with two to four slits" are characteristic of the genus. Tripoplax balaenophila was originally described in the genus Lepidozona (Schwabe \& Sellanes 2004), with a slit formula of 1-2 for intermediate valves. In 2010, however, it was transferred to Tripoplax (as a new combination), following a recent redefinition of this genus (Clark 2008), without further comments on the slit formula (Schwabe \& Sellanes 2010). This discrepancy in slit number and the assignment of "balaenophila" (with 1-2 slits on intermediate valves) to Tripoplax (with 2-4 slits on intermediate valves) cannot be solved without a more thorough review of both Lepidozona and Tripoplax. Tripoplax species are generally found in higher latitudes in the northern Pacific (Clark 2008), which is the case of the material examined herein $\left(27^{\circ} 08^{\prime} 11^{\prime \prime} \mathrm{N}\right)$. The presence of T. balaenophila in deep water from off both western Mexico (northern hemisphere) and Chile (southern hemisphere), however, is an interesting issue that needs to be addressed within a general biogeographically context of the distribution of the genera Tripoplax (southeastern and northern Pacific) and Lepidozona (with a worldwide distribution) in the eastern Pacific (Clark 2008; Schwabe \& Sellanes 2010).

\section{Conclusions}

Tripoplax cf. balaenophila is a member of the deep-sea mollusks fauna associated with the lower boundary of the OMZ occurring off western Mexico, an habitat characterized by severe hypoxic conditions and colonized by well-adapted species that are generally abundant (Zamorano et al. 2006; Papiol \& Hendrickx 2015). Specimens from Chile were collected in shallower depth compared to the Mexican material, but the OMZ off Chile is also much shallower than in the Mexican Pacific (Helly \& Levin 2004). The presence of T. balaenophila off western Mexico would considerably extend its geographic range (by ca $8280 \mathrm{~km}$ to the north). The disjunct distribution of the genera Tripoplax in the eastern $\mathrm{Pa}$ cific is also an interesting biogeographical issue. Assignment of species to Tripoplax or Lepidozona is still a conflictive issue, in part due to lack of abundant material that would allow for more detailed studies. The existing discrepancy in slit number and the assignment of "balaenophila" to Tripoplax cannot be solved without a more 
thorough review of both genera. Further exploration of the deep-sea in the eastern Pacific might also bring additional specimens that would fill the gap in the distribution range of the deep-water Polyplacophora.

\section{Methods}

Specimens were collected during the TALUD XV cruise, off the west coast of the Baja California Peninsula (July 29 to August 6, 2012) aboard the R/V "El Puma", of the Universidad Nacional Autónoma de México (UNAM). Positional coordinates for each sampling station were obtained using a GPS navigation system. Depth was measured with a digital recorder. Epibenthic temperature and oxygen concentration were measured ca $10 \mathrm{~m}$ above bottom level with a Seabird CTD- $\mathrm{O}_{2}$ probe. Oxygen concentrations were also double-checked with the Winkler method using water samples collected in closing bottles near bottom. The specimens were captured with a standard benthic sledge $(2.35 \mathrm{~m}$ width, $0.9 \mathrm{~m}$ high) equipped with a modified shrimp net (ca $5.5 \mathrm{~cm}$ stretched mesh size) with a ca $2.0 \mathrm{~cm}(3 / 4 ")$ internal lining net. The material collected during this survey is deposited in the Regional Collection of Marine Invertebrates (EMU), at UNAM in Mazatlán, Mexico. To confirm the identification, the radula was extracted following recent literature (Geiger et al. 2007) and photographed with a Scan Electronic Microscope (SEM). Dorsal girdle scales (also photographed with the SEM) and disarticulated valves were also examined. Entire specimens and the photographs were compared to the original description (Schwabe \& Sellanes 2004). Photographs were sent to Boris Sirenko (Russian Academy of Sciences, Moscow) and to Enrico Schwabe (Bavarian State Collection of Zoology, Munich) for comparison with the type material. Ethics, consent and permissions have been followed in the manuscript. Collection of specimens was covered by permit FAUT-0053 of the National Institute of Ecology, Mexico.

\section{Abbreviations \\ St.: station; TL: total length.}

\section{Competing interests}

The authors declare that they have no competing interests.

\section{Authors' contributions}

NYSM carried out the revision of the specimens, elaborate the manuscript draft and processed the illustrations. MEH is responsible of the TALUD cruises, participate in the organization and final version of the manuscript. All authors read and approved the final manuscript.

\section{Authors' information}

NYSM is a postgraduate student at UNAM and this contribution is part of her master thesis. MEH is a senior scientist at UNAM and head scientist of the TALUD project.

\section{Acknowledgments}

We are grateful to Boris Sirenko (Russia) for his guidance during identification of chitons. We are also grateful to Enrico Schwabe (Germany) who helped with the identification of our material of Tripoplax, provided very useful comments on drafts of this contribution and collection data of additional material. One of us (NYSM) acknowledges Paul Valentich-Scott and Daniel Geiger, Santa Barbara Museum of Natural History, for their hospitality and support during her visit to the museum. The support of the Santa Barbara Museum with the operation of the SEM is also strongly acknowledged. We are grateful for comments by two referees, one anonymous and Douglas J. Eernisse, that greatly helped to improve the manuscript. We thank $D$. Serrano for providing information on the oxygen profile at the sampling station and J. Salgado Barragán for his technical help with Fig. 1i, j. Ship time of the research cruise TALUD XV carried aboard the RN "El Puma" was funded by the Universidad Nacional Autónoma de México and CONACYT. This study was partly supported by CONACYT (Project 179467). One of us (NYSM) is beneficiary of a CONACyT postgraduate grant.

\section{Author details \\ 'Posgrado en Ciencias del Mar y Limnología, Universidad Nacional Autónoma de México, Unidad Académica Mazatlán, Mazatlán, Sinaloa, México. ${ }^{2}$ Unidad Académica Mazatlán, Instituto de Ciencias del Mar y Limnología, Universidad Nacional Autónoma de México, P.O. Box 811, Mazatlán 82000, Sinaloa, México.}

Received: 19 February 2016 Accepted: 23 February 2016 Published online: 11 April 2016

\section{References}

Ávila SP, Sigwart J. New records for the shallow-water chiton fauna (Mollusca: Polyplacophora) of the Azores (NE Atlantic). ZooKeys. 2013;312:23-38. doi:10. 3897/zookeys.312.4768.

Berry SS. Notes on West American Chitons II. Proc Calif Acad Sci. 1919;9:1-36.

Clark RN. A new species of Mopalia (Polyplacophora: Mopaliidae) from the northeast Pacific. Veliger. 1991;34:309-13.

Clark RN. The chiton fauna of the Gulf of California rhodolith beds (with descriptions of four new species). Neumonia. 2000:43:1-8.

Clark RN. Two new chitons of the genus Tripoplax Berry, 1919 from the Monterrey Sea Canyon. Am Malacol Bull. 2008;25:77-86.

Dall WH. Description of a new species of chitons from the Pacific coast of America. Proc US Natl Mus. 1919;55:499-515.

Diaz RJ, Rosenberg R. Marine benthic hypoxia: a review of its ecological effects and the behavioral responses of benthic macrofauna. Oceanogr Mar Biol Annu Rev. 1995;33:245-303.

Eernisse DJ. Class Polyplacophora. In: Valentich-Scott P, Blake JA, editors. Taxonomic Atlas of the Benthic Fauna of the Santa Maria Basin and Western Santa Barbara Channel. The Mollusca Part 1 - The Aplacophora,

Polyplacophora, Scaphopoda, Bivalvia and Cephalopoda. Santa Barbara: Santa Barbara Museum of Natural History; 1998. p. 49-73.

Ferreira AJ. The family Lepidopleuridae (Mollusca: Polyplacophora) in the eastern Pacific. Veliger. 1979;22:145-65.

Flores-Campaña LM, González-Montoya MA, Ortiz-Arellano MA, Arzola-González JF. Estructura poblacional de Chiton articulatus (Sowerby, 1832) en las islas Pájaros y Venados de la bahía de Mazatlán, Sinaloa, México. Rev Mex Biodivers. 2007;78:23-31.

Galeana-Rebolledo L, Flores-Garza R, Torreblanca-Ramírez C, García-lbáñez S, Flores-Rodríguez P, López-Rojas VP. Biocenosis de Bivalvia y Polyplacophora del intermareal rocoso en playa Tlacopanocha, Acapulco, Guerrero, México. Lat Am J Aquat Res. 2012;40:943-54. doi:10.3856/vol40-issue4-fulltext-11.

Geiger DL, Marshall BA, Ponder WF, Sasaki T, Warén A. Techniques for collecting, handling, and preparing small molluscan specimens. Molluscan Res. 2007;27: $1-50$.

Helly JJ, Levin LA. Global distribution of naturally occurring marine hypoxia on continental margins. Deep-Sea Res I. 2004;51:1159-68.

Hendrickx ME, Serrano D. Impacto de la zona de mínimo de oxígeno sobre los corredores pesqueros en el Pacífico mexicano. Interciencia. 2010;35:12-8.

Hendrickx ME, Salgado-Barragán J, Toledano-Granados A, Cordero-Ruiz M. Los moluscos (Pelecypoda, Gastropoda, Cephalopoda, Polyplacophora y Scaphopoda) recolectados en el SE del golfo de California durante las campañas SIPCO a bordo del B/O "El Puma". Elenco faunístico. Rev Mex Biodivers. 2014:85:682-722.

Kaas P, Van Belle RA. Monograph of living chitons (Mollusca: Polyplacophora). 2, Suborder Ischnochitona, Ischnochitonidae: Schizoplacinae, Callochitoninae and Lepidochitoninae. Leiden: E. J. Brill/W. Backhuys; 1985. 
Kaas P, Van Belle RA. Monograph of living chitons (Mollusca: Polyplacophora). 3, Ischnochitonidae: Chaetopleurinae, Ischnochitoninae (pars). Additions to vols 1, 2. Leiden: E. J. Brill/W. Backhuys; 1987.

Kaas P, Van Belle RA. Monograph of living chitons (Mollusca: Polyplacophora). 4 Suborder Ischnochitonina: Ischnochitonidae: Ischnochitnoninae (continued). Additions to vols 1, 2, 3. Leiden: E. J. Brill/W. Backhuys; 1990.

Papiol V, Hendrickx ME. Ecology of Benthesicymus tanneri Faxon, 1893 off Mexican Pacific slopes. J Crust Biol. 2015;36:50-60.

Puchalski SS, Eernisse DJ, Johnson CC. The effect of sampling bias on the fossil record of chitons (Mollusca, Polyplacophora). Am Malacol Bull. 2008;25:87-95.

Ramírez-Álvarez C, Vélez-Arellano N, García-Domínguez FA, García-lbáñez S, Ituarte C. Hermaphroditism in two populations of Chiton articulatus (Mollusca:Polyplacophora) from the eastern tropical coast of Mexico. Invertebr Reprod Dev. 2014;58:49-52. doi:10.1080/07924259.2013.808709. Reyes-Gómez A. Chitons in Mexican waters. Boll Malacol. 2004;5(supp):69-82. Reyes-Gómez A, Salcedo-Vargas MA. The recent Mexican chiton (Mollusca: Polyplacophora) species. Festivus. 2002;34:17-27.

Saito H, Fujikura K, Tsuchida S. Chitons (Mollusca: Polyplacophora) associated with hydrothermal vents and methane seeps around Japan, with description of three new species. Am Malacol Bull. 2008;25:113-24.

Schwabe E. A summary of reports of abyssal and hadal Monoplacophora and Polyplacophora (Mollusca). Zootaxa. 2008:2008:205-22

Schwabe E, Sellanes J. A new species of Lepidozona (Mollusca: Polyplacophora: Ischnochitonidae) found on whale bones off the coast of Chile. Iberus. 2004; 22:147-53.

Schwabe E, Sellanes J. Revision of Chilean bathyal chitons (Mollusca: Polyplacophora) associated with cold-seeps, including description of a new species of Leptochiton (Leptochitonidae). Org Divers Evol. 2010;10:31-55.

Sellanes J, Neira C, Quiroga E, Teixido N. Diversity patterns along and across the Chilean margin: a continental slope encompassing oxygen gradients and methane seep benthic habitats. Mar Ecol. 2010;31:111-24.

Serrano D. La zona del mínimo de oxígeno en el Pacífico mexicano. In: Zamorano P, Hendrickx ME, Caso M, editors. Biodiversidad y Comunidades del Talud Continental del Pacífico Mexicano. Mexico: Secretaría del Medio Ambiente y Recursos Naturales (SEMARNAT), Instituto Nacional de Ecología (INE); 2012. p. 105-19.

Sirenko Bl. The ancient origin and persistence of chitons (Mollusca, Polyplacophora) that live and feed on deep submerged land plant matter (xylophages). Boll Malacol. 2004;5(supp):111-16.

Stebbins TD, Eernisse DJ. Chitons (Mollusca, Polyplacophora) known from benthic monitoring programs in the Southern California Bight. Festivus. 2009; 41 (special issue):53-100.

Stocks K. Seamount invertebrates: composition and vulnerability to fishing. In: Morato T, Pauly D, editors. Seamounts: biodiversity and fisheries. Fisheries centre research reports 12. Vancouver: University of British Columbia, Canada 2004. p. 17-24.

Zamorano P, Hendrickx ME, Toledano Granados A. Distribution and ecology of deep water mollusks from the continental slope, southeastern Gulf of California, Mexico. Mar Biol. 2006;150:883-92.

\section{Submit your next manuscript to BioMed Central and we will help you at every step:}

- We accept pre-submission inquiries

- Our selector tool helps you to find the most relevant journal

- We provide round the clock customer support

- Convenient online submission

- Thorough peer review

- Inclusion in PubMed and all major indexing services

- Maximum visibility for your research

Submit your manuscript at www.biomedcentral.com/submit

) Biomed Central 